\title{
Growth and Productivity of 'Empire' Apple Trees following a Single Heading-back Pruning Treatment
}

\author{
D.C. Elfving ${ }^{1}$ \\ Horticultural Research Institute of Ontario, P. 0. Box 587, Simcoe, Ont. \\ N3Y 4N5 Canada
}

\section{Additional index words. Malus domestica, M.26 rootstock, yield, shoot growth, trunk enlargement}

Abstract. Dormant heading-back of terminal extension shoots on scaffold limbs on 2year-old 'Empire'/M.26 EMLA apple trees (Malus domestica Borkh.) in Apr. 1985 increased shoot growth from 1- and 2-year-old limb sections. Removing competing shoots to restore a single terminal extension shoot on each scaffold on half the trees in each pruning treatment in May 1985 had little influence on shoot growth. Annual trunk enlargement was reduced in 1985 and 1986 by heading-back pruning in 1985. Trunk cross-sectional area in Fall 1989 remained smaller for trees only headed back once, in 1985. Yields were decreased in 1986 through 1989 by heading-back treatments applied in 1985.

Early production is crucial to the economic success of a new apple orchard today. Annual heading-back of the previous-season's terminal and lateral shoots by about one-fourth has been recommended to stimulate fruiting-wood formation and increase cropping (Heinicke, 1975). Heinicke pointed out that this approach would reduce the first crop, but that "future crops will be larger due to the greater volume of fruiting branches".

Dormant heading of 1-year-ord shoots only once increased shoot growth and decreased flowering and fruiting for up to 2 years in both limbs and whole trees (Elfving and Forshey, 1976a, 1976b; Gardner, 1917; Mika, 1969). Heading all 1-year-old shoots by onethird or two-thirds each year for 5 years or heading all l-year-old shoots by one-fourth plus restoration of a single terminal extension shoot shortly after bloom each year for 6 years increased shoot growth, decreased bloom, reduced 'Delicious' yield by $25 \%$ over 4 years (Lord and Damon, 1983; Lord et al., 1984), or reduced flowering and yield in 'McIntosh' but not in 'Melba' (Mika et al., 1983).

'Empire' apple is an increasingly impor-

Received for publication 13 Nov. 1989. Mention of a product or trade name does not constitute a guarantee or warranty of the product by the Hort. Res. Inst. of Ontario nor an endorsement over similar products not mentioned. The cost of publishing this paper was defrayed in part by the payment of page charges. Under postal regulations, this paper therefore must be hereby marked advertisement solely to indicate this fact.

'Research Scientist. tant cultivar in Ontario, but little research has been carried out on its responses to pruning during canopy development. The trial reported here examined the effects of headingback pruning once during the canopy establishment phase on subsequent growth and fruiting of young, vigorously growing 'Empire' trees.

In 1983, 1-year-old whips of 'Empire'/ M.26 EMLA were planted on 8 Apr. at a spacing of $3.7 \times 5.5 \mathrm{~m}$ on a well-drained Bookton soil composed of sandy till over glaciolacustrine clays. This site had contained an apple orchard until 1981, when it was removed. The soil was deep-plowed in 1982, large roots were removed, $\mathrm{pH}$ was adjusted to 26.5 with lime, and the soil was fumigated with Vorlex-CP (Nor-Am Chemical Co., Wilmington, Del.) at 225 liter $\cdot$ ha $^{-}{ }^{1}$ in Sept. 1982. A grass sod was sown in the row middles following planting, and a 1.2$\mathrm{m}$-wide herbicide strip was maintained in the rows. The trees were trained to the freestanding, central-leader system; pruning and scaffold-limb selection were carried out as recommended, heading only the leader each year (Tehrani et al., 1988). Pest-control and fertilization practices were according to local recommendations (Ont. Min. Agr. and Food, 1988).

At the time the trial began in Apr. 1985, each tree had three or four scaffold limbs composed of 1- and 2-year-old limb sections, plus another four to five upper scaffolds composed only of a single 1-year-oldshoot each. Three levels of heading-back pruning were arranged in factorial combination with or without removal of competing shoots from limb terminals shortly after shoot growth began on single, whole-tree plots in a randomized complete-block design with seven replications. In each tree, the 1-yearold terminal extension shoot on each scaffold was either left intact, or the distal one-third or the distal two-thirds removed on $18 \mathrm{Apr}$. 1985; where heading was done, this represented seven to nine cuts per tree in addition to normal scaffold selection and leader heading. Although there were some lateral shoots on scaffolds with a 2-year-old limb section, these laterals were not headed. On 20 May 1985, when new extension shoots were 10 to $15 \mathrm{~cm}$ long, one to two vigorous competing shoots induced close to the heading cuts were removed by hand to leave a single terminal extension shoot per scaffold. On unheaded trees receiving this treatment, vigorous lateral shoots originating from the first one or two buds below the terminal bud were removed.

One scaffold containing both 1- and 2year-old limb sections was selected on each tree for shoot-growth measurement in 1985. The lengths of the 1- and 2-year-old limb sections were determined, all new shoots originating in 1985 from each limb section were counted and measured, and limb circumference was measured at the junction of each limb with the trunk. Trunk circumference was recorded on each tree each year following leaf drop at a pre-marked location $30 \mathrm{~cm}$ above the soil surface. Fruit numbers and total yield per tree were determined each year, beginning with the first crop in 1986 .

Analyses of regression on heading severity in factorial combination with or without shoot removal assessed the presence of significant linear and curvilinear effects of pruning severity and the homogeneity of intercepts, slopes, and second-order curvatures between shoot-removal levels (Snedecor and Cochran, 1980). Where a difference between slopes, intercepts, or curvatures indicated separate regression relations between shootremoval levels, each regression was individually tested for significant linear and quadratic effects. In the absence of such differences, linear and quadratic effects were tested for the overall regression. Statistical analyses were performed using the General Linear Models procedure of the Statistical Analysis System program package (SAS Institute, Gary, N.C.).

Greater heading severity decreased the number of shoots produced per centimeter limb circumference (LC), although shoot removal altered this relationship (Table 1). Mean shoot length was increased by heading, again differently where shoots were removed. The final lengths of the 1-year-old limb sections following pruning were almost precisely in proportion to heading severity. More-severe heading increased shoot number as well as shoot growth from the 2-year- 
fluenced by the 1985 heading or by shoot removal. The TCSA growth increment in 1989 was greater for trees with shoots removed in 1985. Final TCSA in Fall 1989 was significantly smaller with increasing heading severity for trees in which competing shoots were not removed in 1985, but uninfluenced where shoots also were removed in 1985 .

Yields in 1986, 1987, and 1989 showed strong linear decreases in proportion to 198.5 heading severity (Table 3). In 1988, yield was less for trees headed in 1985 but uninfluenced where shoots were removed in 1985 . Total yield from 1986 to 1989 was similarly reduced for trees headed in 1985, but was unaffected by shoot removal in 1985. Yield efficiency (grams fruit $/ \mathrm{cm}^{2}$ TCSA) was reduced in 1986 and 1987 by increased heading severity, unaffected by any treatment in 1988 , and reduced in 1989 only in trees with shoots removed in 1985.

In this study, heading back terminal 1year-old shoots increased shoot numbers $/ \mathrm{cm}$ LC on 2-year-old wood and increased mean shoot length from both limb sections. Scaffold limbs in this study were oriented between $45^{\circ}$ and $60^{\circ}$ from the vertical. The effects of heading back were largely unmodified by restoration of a single terminal extension shoot after growth began. The reduction in TCSA increment in 1985 suggests that heading increased the allocation of dry matter into shoots, partially at the expense of stem thickening. This response has been documented in 1-year-old rooted apple shoots, where the change in allocation was shown to be proportional to the ratio of old stem length before pruning to that after pruning (Maggs, 1959). Even though the amount of stem tissue removed by heading in the present trial was proportionally much less than in the study by Maggs (1959), the large increase in shoot growth induced by pruning apparently altered shoot-stem dry-weight relations. Barlow (1964) reported a similar change in dry-weight allocation between new and old stem with increasing pruning severity under field conditions. Heading back terminal extension shoots once had a-profound and extended negative effect on subsequent yield. Yield reductions over several years have been reported where heading back was done annually (Lord and Damon, 1983; Lord et al., 1984; Mika, 1975; Mika et al., 1983). Some reports indicate positive, as well as negative, effects of heading pruning on yield (Christensen, 1975; Ferree and Rhodus, 1987), but these studies involved heading trees at planting. More-severe pruning shifts the vegetative growth-fruiting relationship away from cropping (Forshey and Elfving, 1989), but little is known about the duration of such responses.

In this study, the trend in yield response over time suggests that both loss of spurs and reduced tree size played a role. The strong yield reductions in 1986 and 1987 probably reflected losses in spurs due to removal of buds by pruning and stimulation of growing points to develop into shoots rather than spurs in 1985 . By 1989, the trees in this study had much larger canopies, yet TCSA still suggested reduced tree size in proportion to 1985 heading treatments where no shoots were removed in 1985. Loss of yield-efficiency effects in 1988 and 1989 for trees without shoots removed in 1985 supports the hypothesis that tree size accounted for reduced yield in the later years.

After five growing seasons (1985-89), the trees had not fully overcome the effects of the heading back in Spring 1985. No increased yields in response to heading-back pruning were observed during the 5 years of this study. Effects of heading back were only slightly modified by removal of competing shoots. The results reported here indicate that heading scaffold limbs only once during tree training can have signficant and long-term negative effects on 'Empire' apple tree productivity.

\section{Literature Cited}

Barlow, H.W.B. 1964. An interim report on a long-term experiment to assess the effect of cropping on apple tree growth. Annu. Rpt. E. Mailing Res. Sta. 1963:84-93.

Christensen, J.V. 1975. Formning af 2-ars aeble- traeer til taetplantning. Tidsskr. for Planteavl 79:405-412.

Elfving, D.C. and C.G. Forshey. 1976a. Growth and fruiting responses of vigorous apple branches to pruning and branch orientation treatments. J. Amer. Soc. Hort. Sci. 101:290-293.

Elfving, D.C. and C.G. Forshey. 1976b. Responses of vigorous 'Delicious' apple trees to pruning and growth regulator treatments. J. Amer. Soc. Hort. Sci. 101:561-564.

Ferree, D.C. and W.T. Rhodus. 1987. Early performance and economic value of feathered apple trees on semi-standard rootstocks. J. Amer. Soc. Hort. Sci. 112:906-909.

Forshey, C.G. and D.C. Elfving. 1989. The relationship between vegetative growth and fruiting in apple trees. Hort. Rev. 11:229-287.

Gardner, V.R. 1917. The winter heading-back and thinning-out of apple shoots in young trees. Ore. Agr. Ext. Serv. Bul. 146:57-78.

Heinicke, D.R. 1975. High-density apple orchards-planning, training and pruning. U.S. Dept. Agr. Hdbk. 458.

Lord, W.J. and R.A. Damon, Jr. 1983. Growth and fruiting responses of 'Redspur Delicious' apple trees to pruning treatments. J. Amer. Soc. Hort. Sci. 108:867-871.

Lord, W.J., R.A. Damon, Jr., J. Sincuk, and K.E. Slosser. 1984. Heading cuts on apple trees reduce yields. Fruit Notes 49(2):1-6.

Maggs, D.H. 1959. The pruning response of oneyear apple trees. Ann. Bot. 23:319-330.

Mika, A.L. 1969. Effects of shoot-bending and pruning oR growth and fruit bud formation in young apple trees. Hort. Res. 9:93-102.

Mika, A.L. 1975. The mechanism of fruiting inhibition caused by pruning in young apple trees. Fruit Sci. Rpt. 2:31-42.

Mika, A.L., M.J. Grochowska, A. Karaszewska, and M.W. Williams. 1983. Effects of dormant and summer pruning, disbudding, and growth retardants on growth, flower bud formation, and fruiting of young apple trees. J. Amer. Soc. Hort. Sci. 108:655-660.

Ontario Ministry of Agriculture and Food. 1988. Fruit production recommendations. Ont. Min. Agr. and Food Publ. 360.

Snedecor, G.W. and W.G. Cochran. 1980. Statistical methods, 7 th ed. Section 18.9. Iowa State Univ. Press, Ames. p. 385-388.

Tehrani, G., N.W. Miles, and D.C. Elfving. 1988. Training and pruning fruit trees. Ont. Min. Agr. and Food Publ. 392. 